\title{
The potential of plant and fungal proteins in the control of gastrointestinal nematodes from animals
}

\author{
Potencial de proteínas de plantas e fungos no controle de nematoides gastrintestinais de animais \\ Alexandra Martins dos Santos Soares ${ }^{1}$; Lêdia Feitosa Wanderley ${ }^{1}$; Livio Martins Costa Junior ${ }^{2 *}$ \\ ${ }^{1}$ Laboratório de Bioquímica Vegetal, Curso de Engenharia Química, Centro de Ciências Exatas e Tecnologias, Universidade Federal \\ do Maranhão - UFMA, São Luís, MA, Brasil \\ ${ }^{2}$ Laboratório de Controle de Parasitos, Departamento de Patologia, Centro de Ciências Biológicas e da Saúde, Universidade Federal \\ do Maranhão - UFMA, Sáo Luís, MA, Brasil
}

Received January 28, 2019

Accepted May 27, 2019

\begin{abstract}
Gastrointestinal nematode infection is an important cause of high economic losses in livestock production. Nematode control based on a synthetic chemical approach is considered unsustainable due to the increasing incidence of anthelmintic resistance. Control alternatives such as the use of natural products are therefore becoming relevant from an environmental and economic point of view. Proteins are macromolecules with various properties that can be obtained from a wide range of organisms, including plants and fungi. Proteins belonging to different classes have shown great potential for the control of nematodes. The action of proteins can occur at specific stages of the nematode life cycle, depending on the composition of the external layers of the nematode body and the active site of the protein. Advances in biotechnology have resulted in the emergence of numerous protein and peptide therapeutics; however, few have been discussed with a focus on the control of animal nematodes. Here, we discuss the use of exogenous proteins and peptides in the control of gastrointestinal.
\end{abstract}

Keywords: Bioactive proteins, protease, chitinase, lectin, peptides.

\section{Resumo}

A infecção por nematoides gastrintestinais é uma importante causa de grandes perdas econômicas na pecuária. O controle de nematoides com compostos químicos sintéticos é considerado insustentável devido ao aumento da resistência anti-helmíntica. Alternativas de controle, como o uso de produtos naturais, estáo se tornando relevantes do ponto de vista ambiental e econômico. As proteínas são macromoléculas com várias propriedades que podem ser obtidas de uma ampla gama de organismos, incluindo plantas e fungos. Proteínas pertencentes a diferentes classes têm mostrado grande potencial para o controle de nematoides. A ação das proteínas pode ocorrer em estágios específicos do ciclo de vida do nematoide, dependendo da composição das camadas externas do parasito e do sítio ativo da proteína. Avanços na biotecnologia resultaram no surgimento de numerosas terapias de proteínas e peptídeos; no entanto, pouco foi discutido com foco no controle de nematoides parasitos de animais. Na presente revisão foi discutido o uso de proteínas exógenas e peptídeos no controle de nematoides gastrintestinais, os mecanismos sugeridos de ação, e os desafios e perspectivas para o uso dessas biomoléculas como uma classe de anti-helmínticos.

Palavras-chave: Proteínas bioativas, protease, quitinase, lectina, peptídeos.

\section{Introduction}

Gastrointestinal nematodes (GINs) are a worldwide health problem for animals. In livestock, parasitic diseases constitute one of the biggest barriers to animal production, directly affecting productivity and leading to high economic losses

*Corresponding author: Livio Martins Costa Junior. Laboratório de Controle de Parasitos, Departamento de Patologia, Centro de Ciências Biológicas e da Saúde, Universidade Federal do Maranhão, Av. dos Portugueses, 1966, Cidade Universitária do Bacanga, CEP 65080-805, São Luís, MA, Brasil. e-mail: livio.martins@ufma.br; livioslz@yahoo.com
(GRISI et al., 2014). The increasing nematode resistance to commercially available drugs, in addition to the presence of residues from these drugs in the environment and in foods of animal origin (SALGADO \& SANTOS, 2016), which may affect consumer health, has encouraged research to develop alternative methods for control. Based on this scenario, it remains an important challenge to find biologically active compounds that are effective and at the same time less harmful to the environment. 
An alternative is to exploit naturally occurring compounds that exist in fungi and plants (BEHNKE et al., 2008; LIU et al., 2016). Currently, there is increasing progress in the exploration of biomolecules for controlling parasites, mostly regarding compounds of plant origin with satisfactory results. However, most studies on the use of anthelmintic plant and fungi compounds against GINs are carried out with non-protein-based low-molecular-weight compounds. Proteins, the most abundant macromolecules in living beings, perform various functions, including the formation of structure and the regulation of metabolism and defense (MOHANTY et al., 2014). Among a wide range of natural products, proteins have emerged as promising molecules due to their high pharmacological and biotechnological potential (DIMITROV, 2012).

Advances in biotechnology have resulted in the emergence of numerous protein and peptide therapeutics. In the last 10 years, the number of papers published about therapeutic proteins has increased by $88 \%$. The numbers of therapeutic proteins approved and under clinical trials in humans are increasing exponentially (PATEL et al., 2014). The use of genetic engineering and drug delivery to produce and distribute therapeutic proteins have also undergone development. However, few studies have explored the use of proteins against GINs. This review discusses the use of proteins from plants and fungi as a potential alternative tool for the control of GINs in animals.

\section{Plant and Fungal Proteins}

Plants possess a wide spectrum of defenses against infections, including phytonematodes. These plant proteins are called pathogenesis-related (PR) proteins. PR proteins, such as protease (Hydrolase), lipase (Hydrolase), and collagenase (metalloproteinases) are capable of causing harmful effects on the cuticle structure of phytonematodes, leading to death or decreasing motility (MILLER \& SANDS, 1977). The effectiveness of PR proteins in plant defense is already well known, and it has been proven that PR proteins can also be effective in the control of parasites and pathogens in other living beings.

Similar to plants, fungi can also be sources of bioactive proteins. Nematophagous fungi are natural enemies of free-living nematodes and gastrointestinal helminth parasites. They can be found in diverse environments and have been shown to be effective as biocontrol agents (KERRY \& HIDALGO, 2004; ARAUJO et al., 2013). Secreted proteins play important roles in fungus-host and fungus-environment interactions as well as in fungal pathogenicity. Acid phosphatases, chitinases, chitosanases, lipases and serine proteases are hydrolases produced by nematophagous species. These enzymes are crucial in the infection process (SEGERS et al., 1994; WANG et al., 2006; CRUZ et al., 2009; MI et al., 2010; ARANDA-MARTINEZ et al., 2016; ESCUDERO et al., 2016). These enzymes are responsible for the physical and physiological destabilization of the nematode cuticle and may interfere with its life cycle and/or lead to death (BRAGA et al., 2011; LIN et al., 2018). The penetration of the nematode cuticle by the fungi has been assumed to be due to a combination of physical activity and hydrolytic enzymes including phosphatases (WANG et al., 2006).
Although the use of proteins derived from fungi with anthelmintic activity is extremely promising, few papers address this subject, thus having little information on extraction, purification or laboratory/industrial scale protein production for use as anthelmintic.

\section{Proteins Targeting Gastrointestinal Nematodes}

The action of proteins can occur at specific stages of the nematode life cycle, depending on the composition of the external layers of the nematode and the active site of the protein. However, further studies are needed to evaluate the biochemical properties of these effects. For instance, although the cuticle substrates for proteases are still unknown, they are strong potential candidates for novel targets of much-needed new drugs or vaccines (PAGE et al., 2014).

The egg membrane is formed by different layers: a basal layer composed of lipids and proteins; a chitin medial layer; and an outer vitelline layer (MANSFIELD et al., 1992). Thus, the cuticle and the egg membrane can be targets for attack by proteins such as proteases, lectins, chitinases, lipases and collagenases. The activity of plant proteins against Haemonchus contortus eggs has recently been suggested (SALLES et al., 2014; SOARES et al., 2015a), indicating a new direction for research aiming to develop new anthelmintic products.

It has been suggested that some proteins are nematode cuticle-degrading enzymes or act on the egg membrane. The cuticle is an outer covering essential for the growth, movement and survival of the nematodes. This structure may differ among nematode species and even among life stages of the same species; however, it presents a basic structural form consisting essentially of proteins with small amounts of lipids and carbohydrates. The cuticle has layers with different compositions: the basal and medial layers, consisting of collagen; the epicuticular and outer cortical regions, consisting of other noncollagenous proteins; and nonstructural proteins associated with the external surface as glycoproteins (BIRD \& BIRD, 1991; FETTERER \& RHOADS, 1993).

The third-and fourth-stage larvae (L3 and L4, respectively) and the adult stages of $H$. contortus each express a unique, restricted set of surface proteins. In the adult nematode, $80 \%$ or more of the cuticle is composed of collagens. In addition to the quantitative increases in cuticular collagens during development, qualitative differences have also been observed. Some adult surface proteins are glycosylated and show a strong affinity for wheat germ agglutinin (FETTERER \& RHOADS, 1993; PAGE et al., 2014).

\section{Anthelmintic Proteins}

Plant extracts or latex, which is rich in proteins, have been used for the treatment of worm infections by the native inhabitants of Central and South America since over a century ago (LEVECKE et al., 2014; LIEN \& LOWMAN, 2003). Indeed, European doctors used proteases such as papain and papaya latex for the treatment of worms in the 19th century (LIU et al., 2011; LUO et al., 2013). 


\section{Proteases}

Proteases can be classified as acidic ( $\mathrm{pH}$ from 2.0 to 6.0), neutral ( $\mathrm{pH}$ of 6.0 to 8.0 ) or alkaline ( $\mathrm{pH} 8.0$ to 13.0 ) according to the optimum $\mathrm{pH}$ for activity (LIU \& KOKARE, 2017). The optimum $\mathrm{pH}$ of a protein has a practical use in gastrointestinal nematode control because the $\mathrm{pH}$ of the digestive organs varies. Thus, the strength of the effect of some proteins against nematodes can depend on their habitat. Some proteases require additional chemical components to be active, such as metal ions or complex organic molecules named coenzymes.

Plant latex, which is normally rich in proteases, has traditionally been used to treat parasitic infections in humans (HANSSON et al., 1986) and animals (CALDWELL \& CALDWELL, 1929; SATRIJA et al., 1994), but one of the first reports of the protein nature of the anthelmintic activity was made by Robbins (1930), who identified a cysteine protease named ficin, from Ficus spp., capable of degrading the cuticle of Ascaris suum. A similar effect was observed when $A$. suum and $H$. contortus were treated in vitro with bromelain from Ananas comosus (BERGER \& ASENJO, 1939; DOMINGUES et al., 2013) and pure crystalline papain from Carica papaya (BERGER \& ASENJO, 1940). These proteins quickly led to in vitro ulcerations in the cuticle of the nematode, followed by digestion. However, in vivo evaluation of bromelain on sheep did not reduce $H$. contortus (DOMINGUES et al., 2013)

Cysteine proteases produced by plants play a crucial role not only in the regulation of metabolism but also, predominantly, in defense, exhibiting direct action on herbivores, pathogens and nematodes (WANG et al., 2014). It is believed that GINs in the parasitic life cycle does not express defenses against cysteine proteases because mammals do not secrete these enzymes in the digestive tract (BEHNKE et al, 2008). Thus, cysteine proteases are under investigation in bioassays in vitro and in vivo against nematode parasites in animals.

Cysteine proteases from papaya latex (C.papaya) are effective in controlling infection by Trichuris suis in pigs with low (inoculation of 300 eggs) and high (inoculation of 3,000 eggs) levels of infection. A single dose of $450 \mu \mathrm{mol}$ of this protease had higher efficacy than a single dose of $400 \mathrm{mg}$ albendazole. The animals showed a reduction in the fecal egg count and worm burden, with an efficiency higher than 97\% (LEVECKE et al., 2014).

The anthelmintic action of cysteine proteases was evaluated for parasites of different regions of the digestive tract in experiments using small rodent nematodes as a model. Different plant cysteine proteases were shown to be potent in vivo against the nematodes Heligmosomoides bakeri (small intestine parasite) and Trichuris muris (large intestine parasite). Therefore, the cysteine proteases remained active and resistant to hydrolysis while passing through the entire gastrointestinal tract. However, anthelmintic action against Protospirura muricola (stomach parasite) was observed only when the acidity of the host's stomach was neutralized before the administration of proteases, indicating that enzymes can be effective when administered appropriately (STEPEK et al., 2006; 2007a, b).

Although papain and papaya latex were used for the treatment of worms in the 19th century, the enzymatic basis was more recently discovered (BEHNKE et al., 2008). In vitro nematicide activity against $H$. bakeri, T. muris and $P$. muricola was observed, and the mechanism of action of these proteases was proposed. Both the crude extract and the purified enzymes of papaya latex (C. papaya), fig (Ficus benjamina and Ficus carica), pineapple (A. comosus) and Asclepias sinaica were effective against female and male adults of the nematode $H$. bakeri. The purified proteases showed higher efficiency than crude extracts, and the anthelmintic action of the crude extracts was completely inhibited by a cysteine protease inhibitor (E-64) (STEPEK et al., 2005). Additionally, it was observed that the action of papain on $H$. bakeri is independent of host sex and worm load (LUOGA et al., 2015). The same crude extracts that showed efficacy against $H$. bakeri were also active against $T$. muris and $P$. muricola. The authors suggest that cysteine proteases attack the nematode cuticles, reducing motility. This attack weakens the cuticle, and the hydrostatic pressure inside the body leads to parasite disintegration (STEPEK et al., 2006, 2007a). However, actinidain, a protease obtained from a fruit juice, did not damage the cuticle of nematodes, suggesting that the efficacy depends on the protease type and the nematode target (STEPEK et al, 2006, 2007a, b).

The sequence of events of nematode-trapping fungi infection occur by a combination of physical activity and hydrolytic enzymes including proteases as subtilisin-like serine protease family and collagenase, a metalloprotease (JANSSON \& NORDBRING-HERTZ, 1988; WANG et al., 2006). A subtilisin-like serine protease from Arthrobotrys oligospora fungus (produced in heterologous system Pichia pastoris) exhibits anthelmintic action against Caenorhabditis elegans and $H$. contortus. The recombinant protein displayed biological activity to immobilize the nematodes by degrading their cuticles, inducing death (JUNWEI et al., 2013). The fungus Duddingtonia flagrans produces a serine protease capable of reducing by $58 \%$ the third-stage larvae (L3) of the cyathostome (Nematoda-Cyathostominae) (BRAGA et al., 2012). This class of protease is involved in the infection process carried out by D. flagrans and can change according to which nematode are infect as showed by Cruz et al. (2015) in trichostrongylides and free-living nematodes. However, it is believed that nematodes have defenses against this protease class since they are abundant in the gut of mammals (ZANG \& MAIZELS, 2001).

Collagenases are proteases that catalyze the hydrolysis of collagen, a component of the cuticle of nematodes. However, to the best of our knowledge, there are no reports on the application of these enzymes in the control of GINs. The proteins of the egg membrane of $H$. contortus are not degraded by collagenase, probably because collagen plays no important role in maintaining this structure (MANSFIELD et al., 1992).

\section{Chitinases}

These enzymes are widely distributed in nature and are found in many living organisms, where they play roles related to nutrition, defense, nutrition and parasitism. In plants, chitinases are produced mainly for defense against insects and several stages of nematodes, such as eggs (JAVED et al., 2013). Recently, plant chitinases have also been associated with activity that reduces GIN egg hatching (SOARES et al., 2015a). 
It is well known that chitinase plays an essential role in the success of nematicidal fungi (TIKHONOV et al., 2002). The treatment of nematode eggs with chitinase causes the formation of large vacuoles in the chitin layer and loss of integrity in the vitelline layer. Chitinases from the nematophagous fungi D. flagrans and P. chlamydosporia presented anthelmintic properties against the larvae of Strongyloides westeri, a small intestine parasite from horses (BRAGA et al., 2014). However, depending on the chitinase source, different effects on hatchability can be observed. For instance, fungal chitinase reduced Meloidogyne javanica egg hatching, while bacterial chitinase increased egg hatching (KHAN et al., 2004). It is known that chitinases are able to degrade the cuticle of $H$. contortus eggs (MANSFIELD et al., 1992) and the effect of variables to in vitro chitinases production by nematophagous fungi are already determined (SOARES et al., 2015b). However, to the best of our knowledge, the potential of this enzyme against GINs is poorly studied.

\section{Lectins}

The toxicity of lectins is related to their binding capacity on the target organisms (BUTSCHI et al., 2010). Lectin binding on the intestinal epithelium surface of $C$. elegans inhibits larval development and may lead to death of the nematode (BUTSCHI et al., 2010). Despite the specificity of lectins for certain carbohydrates, these proteins can affect nematodes that possess similar glycan structures. For instance, the free-living nematode $C$. elegans has similar glycan structures to those of $H$. contortus (PASCHINGER $\&$ WILSON, 2015). The larval development of $H$. contortus is affected by low amounts of four different fungal lectins that bind to the larval gut and interact with gastrodermal glycans of adult tissue (HEIM et al., 2015).

Different lectins (phytohemagglutinin, wheat germ agglutinin and concanavalin A) inhibit the larval feeding of GINs of sheep and goats in vitro: Teladorsagia circumcincta, Trichostrongylus colubriformis and $H$. contortus (RIOS-DE-ALVAREZ et al., 2012a). Although the mechanism of action of these lectins was not well elucidated in this study, the authors observed that wheat germ agglutinin causes damage to the cuticle of T. circumcincta. Previous studies indicated that ConA, soybean agglutinin (SBA) and WGA inhibit the migration of Strongyloides ratti larvae by binding to chemical sensors around the mouth or inner labial sensilla of the nematode (TOBATA-KUDO et al., 2005).

Orally administered plant lectins reduce the fecal egg count of sheep infected with $T$. circumcincta and $T$. colubriformis (RIOS-DE-ÁLVAREZ et al., 2012b). It is suggested that lectin directly reduces fertility or indirectly stimulates the immune system, since infected and lectin-supplemented animals showed higher numbers of eosinophils and a tendency toward increased numbers of helper T cells.

Additionally, the lectin of Marasmius oreades fungus has a $\mathrm{Ca}^{++}$-dependent domain with enzymatic activity. The nematicidal activity of $M$. oreades depends on lectin binding to glycosphingolipids, but the proteolytic activity plays a key role in the toxicity mediated by this fungus (WOHLSCHLAGER et al., 2011).

\section{Formulation of Protein Drugs}

Although plant non-protein based low molecular weight compounds have dominated the study of natural products, several proteins are the subject of studies, including research on drug development for oral administration (BARSBY, 2006; MORISHITA \& PEPPAS, 2006; NAGANO \& TSUTSUMI, 2016).

The selection of optimal methods of administration and formulation presents a major challenge to the use of proteins as a new anthelmintic class against GIN in livestock. Therefore, it should take into account the physicochemical characteristics and mechanism of action of the proteins and the parasite habitat. Despite the difficulties inherent in administration, increasing biotechnological advances have been achieved, and various proteins are under study, including drug development for direct oral administration (MORISHITA \& PEPPAS, 2006).

The activity of a protein is strictly dependent on its physicochemical structure. External factors such as temperature, $\mathrm{pH}$, some metals and oxidizing and denaturant agents may cause physical and/or chemical instability in the protein structure. This instability can be reversible or irreversible and can lead to loss of function (NELSON \& COX, 2006).

Another important fact to consider regarding the use of proteins as anthelmintic is their possible degradation by proteases that are abundant in the gastrointestinal tract, including in ruminal fermentations and depending on the local environmental conditions (e.g., $\mathrm{pH}$ ). Thus, stability and protection from degradation are of outmost importance, since they determine the viability of the production of potential anthelmintic proteins. In this context, the formulation is a crucial step in the development of protein drugs for oral delivery because it aims to protect and promote higher availability of the protein in nematode habitat organs.

Much of what is known about the formulation and delivery of protein drugs comes from studies with therapeutic proteins used in the treatment of human physiological disorders. Currently, there are many protein-based drugs in the pharmaceutical market and various strategies and formulations to protect molecules. For instance, emulsions protect the molecule from acidity and intestinal proteases, increasing intestinal permeability; microspheres prevent proteolytic degradation in the stomach and in the upper small intestine and restrict the release of proteins to a more favorable region of the gastrointestinal tract; liposomes improve physical stability and increase the permeability of the cell membrane; and nanoparticles prevent enzymatic degradation and enhance the absorption of the intestinal epithelium. In addition, other approaches, such as hydrophobization, amino acid modification, absorption enhancers and mucoadhesive polymeric systems, can promote the protection, stability and absorption of the protein and allow it to reach the site of action (SHAJI \& PATOLE, 2008; DIMITROV, 2012).

The incorporation of proteins into a chitosan and alginate matrix is an encapsulation method that has shown positive results for the protection of these biomolecules (GEORGE \& ABRAHAM, 2006). The combination of alginate and chitosan protects the protein bovine serum albumin (BSA) from proteolytic enzymes in the fish Sparus aurata. A higher release of the protein into the 
fish lumen was also verified, indicating efficient encapsulation (SAEZ et al., 2015).

Therefore, it is possible to note that beyond baseline prospective research, efforts have been made to elucidate the mechanism of action involved in the anthelmintic capacity of proteins. From this perspective, the use of proteins as drugs has become an increasingly viable reality.

Therapeutic proteins are one of the fastest growing segments in the pharmaceutical market, and their study has undergone several generations of development to achieve increasingly viable products from a commercial point of view. The commercial advantages of these proteins include simplicity of production at relatively low cost, reduced risk of side effects and high bioavailability (MARTIN, 2006).

\section{Final Considerations}

It is necessary to conduct systematic tests and develop appropriate formulations with plant and fungal proteins, taking into account the particularities of each region of the digestive tract, for oral delivery systems. Although there are many techniques for the formulation of protein-based drugs and the possibility of obtaining proteins on an industrial scale by recombinant DNA techniques, most studies are directed to the treatment of human diseases.

Although orally administered proteins have presented nematicidal effects during in vivo experiments with infected animals, some difficulties may occur due to the harsh conditions of the digestive tract, such as the intense proteolysis and low $\mathrm{pH}$ in the stomach, conditions not supported by certain types of proteins. In the current context, the use of preparations enriched in proteins that have nematicidal properties administered in the form of food additives may be a viable solution for use in the field.

At present, taking into account that several studies carried out experiments with enzyme-containing extracts, while only a few experiments have used purified proteins against gastrointestinal nematodes in small ruminants, it seems that proteases, chitinases, lectins and other proteins have the potential to be introduced in the market in the medium term if some points can be clearly elucidated: (I) the chemical characteristics of the proteins; (II) the mode of action and safety; (III) doses; (IV) tolerability; (V) anthelmintic resistance; (VI) increased in vivo performance by combination with other enzymes or treatments; and (VII) large-scale production by molecular biology techniques.

\section{Acknowledgements}

We thank the CNPq (The Brazilian National Council for Scientific and Technological Development) and FAPEMA (Maranhão State Research Foundation) for financial support and the Institute of Science and Technology in Biotechnology of Maranhão, Brazil for facility support. We thank CNPq for awarding a fellowship to Costa-Junior and LM. We also thank Dr. José Tadeu A. Oliveira for his valuable suggestions and assistance and Dr. Herve Hoste for critical review of this manuscript.

\section{References}

Aranda-Martinez A, Lenfant N, Escudero N, Zavala-Gonzalez EA, Henrissat B, Lopez-Llorca LV. CAZyme content of Pochonia chlamydosporia reflects that chitin and chitosan modification are involved in nematode parasitism. Environ Microbiol 2016; 18(11): 4200-4215. http://dx.doi. org/10.1111/1462-2920.13544. PMid:27668983.

Araujo JM, Araújo JV, Braga FR, Ferreira SR, Tavela AO. Predatory activity of chlamydospores of the fungus Pochonia chlamydosporia on Toxocara canis eggs under laboratory conditions. Rev Bras Parasitol Vet 2013; 22(1): 171-174. http://dx.doi.org/10.1590/S1984-29612013000100033. PMid:24252967.

Barsby T. Drug discovery and sea hares: bigger is better. Trends Biotechnol 2006; 24(1): 1-3. http://dx.doi.org/10.1016/j.tibtech.2005.11.001. PMid:16290235.

Behnke JM, Buttle DJ, Stepek G, Lowe A, Duce IR. Developing novel anthelmintics from plant cysteine proteinases. Parasit Vectors 2008; 1(1): 29. http://dx.doi.org/10.1186/1756-3305-1-29. PMid:18761736.

Berger J, Asenjo CF. Anthelmintic activity of crystalline papain. Science 1940; 91(2364):387-388. http://dx.doi.org/10.1126/science.91.2364.387. PMid:17773432.

Berger J, Asenjo CF. Anthelmintic activity of fresh pineapple juice. Science 1939; 90(2335): 299-300. http://dx.doi.org/10.1126/science.90.2335.299-a. PMid:17809477.

Bird AF, Bird J. The structure of nematodes. 2nd ed. San Diego: Academic Press; 1991.

Braga FR, Araujo JM, Silva AR, Araújo JV, Carvalho RV, Soares FEF, et al. Ação ovicida do extrato bruto enzimático do fungo Pochonia chlamydosporia sobre ovos de Ancylostoma sp. Rev Soc Bras Med Trop 2011; 44(1): 116-118. http://dx.doi.org/10.1590/S0037-86822011000100027. PMid:21340423.

Braga FR, Araújo JV, Soares FEF, Geniêr HLA, Queiroz JH. An extracellular serine protease of an isolate of Duddingtonia flagrans nematophagous fungus. Biocontrol Sci Technol 2012; 22(10): 1131-1142. http://dx.doi. org/10.1080/09583157.2012.713912.

Braga FR, Soares FEF, Araujo JM, Fonseca LA, Hiura E, Gava MG, et al. Statistical experimental design to assess the influence of enzymes of nematophagous fungi versus helminths. Res Vet Sci 2014; 97(3): 527532. http://dx.doi.org/10.1016/j.rvsc.2014.09.005. PMid:25267285.

Butschi A, Titz A, Wälti MA, Olieric V, Paschinger K, Nöbauer K, et al. Caenorhabditis elegans $\mathrm{N}$-glycan core beta-galactoside confers sensitivity towards nematotoxic fungal galectin CGL2. PLoS Pathog 2010; 6(1): e1000717. http://dx.doi.org/10.1371/journal.ppat.1000717. PMid:20062796.

Caldwell FC, Caldwell EL. A study of the anthelmintic efficiency of Higuerolatex in the treatment of trichuriasis, with comment as to its effectiveness against Ascaris infestation. Am J Trop Med Hyg 1929; 9(6): 471-482. http://dx.doi.org/10.4269/ajtmh.1929.s1-9.471.

Cruz DG, Costa LM, Rocha LO, Retamal CA, Vieira RA, Seabra $\mathrm{SH}$, et al. Serine proteases activity is important for the interaction of nematophagous fungus Duddingtonia flagrans with infective larvae of trichostrongylides and free-living nematodes Panagrellus spp. Fungal Biol 2015; 119(8): 672-678. http://dx.doi.org/10.1016/j.funbio.2015.03.005. PMid:26228558.

Cruz DG, Silva CP, Carneiro CNB, Retamal CA, Thiébaut JTL, DaMatta RA, et al. Acid phosphatase activity during the interaction of the nematophagous fungus Duddingtonia flagrans with the nematode 
Panagrellus sp. J Invertebr Pathol 2009; 102(3): 238-244. http://dx.doi. org/10.1016/j.jip.2009.08.003. PMid:19679133.

Dimitrov DS. Therapeutic proteins. Methods Mol Biol 2012; 899: 1-26. http://dx.doi.org/10.1007/978-1-61779-921-1_1. PMid:22735943.

Domingues LF, Giglioti R, Feitosa KA, Fantatto RR, Rabelo MD, Oliveira MCS, et al. In vitro and in vivo evaluation of the activity of pineapple (Ananas comosus) on Haemonchus contortus in Santa Inês sheep. Vet Parasitol 2013; 197(1-2): 263-270. http://dx.doi.org/10.1016/j. vetpar.2013.04.031. PMid:23688638.

Escudero N, Ferreira SR, Lopez-Moya F, Naranjo-Ortiz MA, Marin-Ortiz AI, Thornton CR, et al. Chitosan enhances parasitism of Meloidogyne javanica eggs by the nematophagous fungus Pochonia chlamydosporia. Fungal Biol 2016; 120(4): 572-585. http://dx.doi.org/10.1016/j. funbio.2015.12.005. PMid:27020158.

Fetterer RH, Rhoads ML. Biochemistry of nematode cuticle: relevance to parasitic nematodes of livestock. Vet Parasitol 1993; 46(1-4): 103-111. http://dx.doi.org/10.1016/0304-4017(93)90051-N. PMid:8484203.

George M, Abraham TE. Polyionic hydrocolloids for the intestinal delivery of protein drugs: Alginate and chitosan - a review. J Control Release 2006; 114(1): 1-14. http://dx.doi.org/10.1016/j.jconrel.2006.04.017. PMid:16828914.

Grisi L, Leite RC, Martins JRS, Barros ATM, Andreotti R, Cancado PHD, et al. Reassessment of the potential economic impact of cattle parasites in Brazil. Rev Bras Parasitol Vet 2014; 23(2): 150-156. http:// dx.doi.org/10.1590/S1984-29612014042. PMid:25054492.

Hansson A, Veliz G, Naquira C, Amren M, Arroyo M, Arevalo G. Preclinical and clinical studies with latex from Ficus glabrata HBK, a traditional intestinal anthelminthic in the Amazonian area. J Ethnopharmacol 1986; 17(2): 105-138. http://dx.doi.org/10.1016/0378-8741(86)90053-X. PMid:3796016.

Heim C, Hertzberg H, Butschi A, Bleuler-Martinez S, Aebi M, Deplazes P, et al. Inhibition of Haemonchus contortus larval development by fungal lectins. Parasit Vectors 2015; 8(1): 425. http://dx.doi.org/10.1186/s13071015-1032-x. PMid:26283415.

Jansson HB, Nordbring-Hertz B. Infection mechanisms in the fungusnematodes system. In: Poinar GO, Jansson HB, editors. Diseases of Nematodes. Boca Raton: CRC Press; 1988. p. 59-72.

Javed S, Ahmad M, Ahmad MM, Abdin MZ, Hamid R, Khan MA, et al. Chitinases: an update. J Pharm Bioallied Sci 2013; 5(1): 21-29. http:// dx.doi.org/10.4103/0975-7406.106559. PMid:23559820.

Junwei W, Qingling M, Jun Q, Weisheng W, Shuangqing C, Jianxun $\mathrm{L}$, et al. The recombinant serine protease XAoz1 of Arthrobotrys oligospora exhibits potent nematicidal activity against Caenorhabditis elegans and Haemonchus contortus. FEMS Microbiol Lett 2013; 344(1): 53-59. http:// dx.doi.org/10.1111/1574-6968.12154. PMid:23574378.

Kerry BR, Hidalgo L. Application of Pochonia chlamydosporia in the integrated control of root-knot nematode on organically grown vegetable crops in Cuba. IOBC WPRS Bull 2004; 27: 123-126.

Khan A, Williams KL, Nevalainen HKM. Effects of Paecilomyces lilacinus protease and chitinase on the eggshell structures and hatching of Meloidogyne javanica juveniles. Biol Control 2004; 31(3): 346-352. http://dx.doi.org/10.1016/j.biocontrol.2004.07.011.

Levecke B, Buttle DJ, Behnke JM, Duce IR, Vercruysse J. Cyteine proteinases from papaya (Carica papaya) in the treatment of experimental Trichuris suis infection in pigs: two randomized controlled trials. Parasit
Vectors 2014; 7(1): 255. http://dx.doi.org/10.1186/1756-3305-7-255. PMid:24886388.

Lien S, Lowman HB. Therapeutic peptides. Trends Biotechnol 2003; 21(12): 556-562. http://dx.doi.org/10.1016/j.tibtech.2003.10.005. PMid:14624865.

Lin R, Qin F, Shen B, Shi Q, Liu C, Zhang X, et al. Genome and secretome analysis of Pochonia chlamydosporia provide new insight into egg-parasitic mechanisms. Sci Rep 2018; 8(1): 1123. http://dx.doi. org/10.1038/s41598-018-19169-5. PMid:29348510.

Liu R, Mu L, Liu H, Wei L, Yan T, Chen M, et al. Two antimicrobial and nematicidal peptides derived from sequences encoded Picea sitchensis. J Pept Sci 2011; 17(9): 627-631. http://dx.doi.org/10.1002/psc.1380. PMid:21644248.

Liu W, Yang F, Zhang R, Shi X, Lu X, Luan Y, et al. Production of polyketides with anthelmintic activity by the fungus Talaromyces wortmannii using one strain-many compounds (OSMAC) method. Phytochem Lett 2016; 18: 157-161. http://dx.doi.org/10.1016/j.phytol.2016.10.006.

Liu X, Kokare C. Microbial enzymes of use in industry. In: Brahmachari G, editor. Biotechnology of microbial enzymes: production, biocatalysis and industrial applications. Cambridge: Academic Press; 2017. p. 267-298. http://dx.doi.org/10.1016/B978-0-12-803725-6.00011-X.

Luo X, Chen L, Huang Q, Zheng J, Zhou W, Peng D, et al. Bacillus thuringiensis metalloproteinase $\mathrm{Bmp} 1$ functions as a nematicidal virulence factor. Appl Environ Microbiol 2013; 79(2): 460-468. http://dx.doi. org/10.1128/AEM.02551-12. PMid:23124228.

Luoga W, Mansur F, Lowe A, Duce IR, Buttle DJ, Behnke JM. Factors affecting the anthelmintic efficacy of papaya latex in vivo: host sex and intensity of infection. Parasitol Res 2015; 114(7): 2535-2541. http:// dx.doi.org/10.1007/s00436-015-4456-5. PMid:25855350.

Mansfield LS, Gamble HR, Fetterer RH. Characterization of the eggshell of Haemonchus contortus - I. Structural components. Comp Biochem Physiol B 1992; 103(3): 681-686. http://dx.doi.org/10.1016/03050491(92)90390-D. PMid:1458842.

Martin P. Beyond the next generation of therapeutic proteins. Bio Tech Int 2006; 18(5): 17-19.

Mi Q, Yang J, Ye F, Gan Z, Wu C, Niu X, et al. Cloning and overexpression of Pochonia chlamydosporia chitinase gene pcchi44, a potential virulence factor in infection against nematodes. Process Biochem 2010; 45(5): 810814. http://dx.doi.org/10.1016/j.procbio.2010.01.022.

Miller PM, Sands DC. Effects of hydrolytic enzymes on plant-parasitic nematodes. J Nematol 1977; 9(3): 192-197. PMid:19305592.

Mohanty B, Mahanty A, Ganguly S, Sankar TV, Chakraborty K, Rangasamy A, et al. Amino Acid compositions of 27 food fishes and their importance in clinical nutrition. J Amino Acids 2014; 2014: 269797. http://dx.doi. org/10.1155/2014/269797. PMid:25379285.

Morishita M, Peppas NA. Is the oral route possible for peptide and protein drug delivery? Drug Discov Today 2006; 11(19-20): 905-910. http://dx.doi.org/10.1016/j.drudis.2006.08.005. PMid:16997140.

Nagano K, Tsutsumi Y. Development of novel drug delivery systems using phage display technology for clinical application of protein drugs. Proc Jpn Acad, Ser B, Phys Biol Sci 2016; 92(5): 156-166. http://dx.doi. org/10.2183/pjab.92.156. PMid:27169349.

Nelson DL, Cox MM. Lehninger: principios de bioquimica. 4. ed. São Paulo: Editora Sarvier; 2006. 
Page AP, Stepek G, Winter AD, Pertab D. Enzymology of the nematode cuticle: A potential drug target? Int J Parasitol Drugs Drug Resist 2014; 4(2): 133-141. http://dx.doi.org/10.1016/j.ijpddr.2014.05.003. PMid:25057463.

Paschinger K, Wilson IB. Two types of galactosylated fucose motifs are present on N-glycans of Haemonchus contortus. Glycobiology 2015; 25(6): 585-590. http://dx.doi.org/10.1093/glycob/cwv015. PMid:25740940.

Patel A, Cholkar K, Mitra AK. Recent developments in protein and peptide parenteral delivery approaches. Ther Deliv 2014; 5(3): 337-365. http://dx.doi.org/10.4155/tde.14.5. PMid:24592957.

Ríos-de-Álvarez L, Jackson F, Greer A, Bartley Y, Bartley DJ, Grant $\mathrm{G}$, et al. In vitro screening of plant lectins and tropical plant extracts for anthelmintic properties. Vet Parasitol 2012a; 186(3-4): 390-398. http:// dx.doi.org/10.1016/j.vetpar.2011.11.004. PMid:22130336.

Ríos-de-Álvarez L, Jackson F, Greer A, Grant G, Jackson E, Morrison AA, et al. Direct anthelmintic and immunostimulatory effects of oral dosing semi-purified phytohaemagglutinin lectin in sheep infected with Teladorsagia circumcincta and Trichostrongylus colubriformis. Vet Parasitol 2012b; 187(1-2): 267-274. http://dx.doi.org/10.1016/j.vetpar.2012.01.005. PMid:22301376.

Robbins BH. A proteolytic enzyme in ficin, the anthelmintic principle of Leche de Higueron. J Biol Chem 1930; 87: 251-257.

Sáez MI, Barros AM, Vizcaíno AJ, López G, Alarcón FJ, Martínez TF. Effect of alginate and chitosan encapsulation on the fate of BSA protein delivered orally to gilthead sea bream (Sparus aurata). Anim Feed Sci Technol 2015; 210: 114-124. http://dx.doi.org/10.1016/j.anifeedsci.2015.09.008.

Salgado JA, Santos CP. Overview of anthelmintic resistance of gastrointestinal nematodes of small ruminants in Brazil. Rev Bras Parasitol Vet 2016; 25(1): 3-17. http://dx.doi.org/10.1590/S1984-29612016008. PMid:26982560.

Salles HO, Braga ACL, do Nascimento MTSC, Sousa AMP, Lima AR, Vieira LS, et al. Lectin, hemolysin and protease inhibitors in seed fractions with ovicidal activity against Haemonchus contortus. Rev Bras Parasitol Vet 2014; 23(2): 136-143. http://dx.doi.org/10.1590/\$1984-29612014050. PMid:25054490.

Satrija F, Nansen P, Bjorn H, Murtini S, He S. Effect of papaya latex against Ascaris suum in naturally infected pigs. J Helminthol 1994; 68(4): 343346. http://dx.doi.org/10.1017/S0022149X00001619. PMid:7706684.

Segers R, Butt TM, Kerry BR, Peberdy JF. The nematophagous fungus Verticillium chlamydosporium produces a chymoelastase-like protease which hydrolyses host nematode proteins in situ. Microbiology 1994; 140(10): 2715-2723. http://dx.doi.org/10.1099/00221287-140-102715. PMid:8000541.

Shaji J, Patole V. Protein and Peptide drug delivery: oral approaches. Indian J Pharm Sci 2008; 70(3): 269-277. http://dx.doi.org/10.4103/0250474X.42967. PMid:20046732.

Soares AMS, Araújo SA, Lopes SG, Costa-Junior LM. Anthelmintic activity of Leucaena leucocephala protein extracts on Haemonchus contortus. Rev Bras Parasitol Vet 2015a; 24(4): 396-401. http://dx.doi.org/10.1590/ S1984-29612015072. PMid:26689178.
Soares FEF, Jose HQ, Jackson VA, Paula VQ, Angelica SG, Gracilene MAMB, et al. Statistical screening for the chitinase production by nematophagous fungi from Monacrosporium genu. Afr J Microbiol Res 2015b; 9(7): 448-454. http://dx.doi.org/10.5897/AJMR2014.7225.

Stepek G, Buttle DJ, Duce IR, Lowe A, Behnke JM. Assessment of the anthelmintic effect of natural plant cysteine proteinases against the gastrointestinal nematode, Heligmosomoides polygyrus, in vitro. Parasitology 2005; 130(2): 203-211. http://dx.doi.org/10.1017/S0031182004006225. PMid:15727070.

Stepek G, Lowe AE, Buttle DJ, Duce IR, Behnke JM. In vitro and in vivo anthelmintic efficacy of plant cysteine proteinases against the rodent gastrointestinal nematode, Trichuris muris. Parasitology 2006; 132(5): 681689. http://dx.doi.org/10.1017/S003118200500973X. PMid:16448585.

Stepek G, Lowe AE, Buttle DJ, Duce IR, Behnke JM. Anthelmintic action of plant cysteine proteinases against the rodent stomach nematode, Protospirura muricola, in vitro and in vivo. Parasitology 2007a; 134(1): 103112. http://dx.doi.org/10.1017/S0031182006001302. PMid:17032468.

Stepek G, Lowe AE, Buttle DJ, Duce IR, Behnke JM. The anthelmintic efficacy of plant-derived cysteine proteinases against the rodent gastrointestinal nematode, Heligmosomoides polygyrus, in vivo. Parasitology 2007b; 134(10): 1409-1419. http://dx.doi.org/10.1017/S0031182007002867. PMid:17475089.

Tikhonov VE, Lopez-Llorca LV, Salinas J, Jansson HB. Purification and characterization of chitinases from the nematophagous fungi Verticillium chlamydosporium and V. suchlasporium. Fungal Genet Biol 2002; 35(1): 67-78. http://dx.doi.org/10.1006/fgbi.2001.1312. PMid:11860266.

Tobata-Kudo H, Kudo H, Tada I. Strongyloides ratti: chemokinesis of glycolytic enzyme- and lectin-treated third-stage infective larvae in vitro. Parasitol Int 2005; 54(2): 147-152. http://dx.doi.org/10.1016/j. parint.2005.03.001. PMid:15866477.

Wang RB, Yang JK, Lin C, Zhang Y, Zhang KQ. Purification and characterization of an extracellular serine protease from the nematodetrapping fungus Dactylella shizishanna. Lett Appl Microbiol 2006; 42(6): 589-594. http://dx.doi.org/10.1111/j.1472-765X.2006.01908.x. PMid:16706897.

Wang W, Zhang L, Guo N, Zhang X, Zhang C, Sun G, et al. Functional properties of a cysteine proteinase from pineapple fruit with improved resistance to fungal pathogens in Arabidopsis thaliana. Molecules 2014; 19(2): 2374-2389. http://dx.doi.org/10.3390/molecules 19022374. PMid:24566309.

Wohlschlager T, Butschi A, Zurfluh K, Vonesch SC, Auf Dem Keller U, Gehrig P, et al. Nematotoxicity of Marasmius oreades agglutinin (MOA) depends on glycolipid binding and cysteine protease activity. $J$ Biol Chem 2011; 286(35): 30337-30343. http://dx.doi.org/10.1074/jbc. M111.258202. PMid:21757752.

Zang X, Maizels RM. Serine proteinase inhibitors from nematodes and the arms race between host and pathogen. Trends Biochem Sci 2001; 26(3): 191-197. http://dx.doi.org/10.1016/S0968-0004(00)01761-8. PMid:11246026. 